\title{
苳酸代謝異常と尿路結石
}

第 3 篇 回腸を使用した尿路変更術後の尿中への蓚酸排泄量について

$\begin{array}{cllll} & \text { 伊 } & \text { 藤 } & \text { 晴 } & \text { 夫 } \\ & \text { 三 } & \text { 橋 } & \text { 慎 } & \text { 一 } \\ \text { 千葉大学医学部泌尿器科学教室 } & \text { 真 } & \text { 田 } & \text { 寿 } & \text { 彦 } \\ & \text { 村 } & \text { 上 } & \text { 光 } & \text { 右 } \\ & \text { 島 } & \text { 崎渏教授) } & & \text { 淳 }\end{array}$

\section{ABNORMALITIES OF OXALATE METABOLISM AND URINARY LITHIASIS}

III. Urinary Oxalate Excretion after the Replacement of Ureteral

Defects by Ileal Segments

Haruo Ito, Shin-ichi Mitsuhashi, Toshihiko Sanada, Mitsusuke Murakami and Jun Shimazaki

Department of Urology, School of Medicine, Chiba University, Chiba

(Director: Professor Jun Shimazaki)

The association of hyperoxaluria, nephrolithiasis, and intestinal disease was brought to light recently.

Urinary oxalate excretion values after the replacement of ureteral defects with ileal segments were determined. The eight patients were all female and the length of ileal segments used were from 20 to $35 \mathrm{~cm}$. No patient excreted an increased amount of oxalate compared to control wromen.

It was concluded that secondary hyperoxaluria did not seem to occur when ileal segments less than $35 \mathrm{~cm}$ were used for urinary tract.

はじめに

近年, 回腸を切除した患者の尿中への蓚酸排泄量が増 加し，さらに腎結石の形成をみるといらことが報告さ れ，腸疾患と尿路結石との間の因果関係が論じられてき $た^{1) \sim 4)}$. 一方, 泌尿器科飞执いては腸管を用いる尿路変 更術が盛んに行なわれるようになつてきており，この種 の手術のあとでは腎結石が発生しやすいと言われてい る.そこで, 回腸を用いて尿路変更術を行なつた場合に 葆酸代謝異常がみられるかどうかを検討するために本研 究を行なつた。

\section{実験材料ならびに方法}

対象は千葉大学医学部泌尿器科 する尿路変更術を受け 1 年以上経過した 8 名の患者であ る. 患者はすべて24〜48歳までの女性であつた. これら の24時間尿の一部を用いて苳酸の定量を行なつた。ま た，腸疾患のため回腸切除術を数回受けたのちに腎結石
を若起した 1 症例の検索を行なつた。

苳酸の定量は Yarbro \& Simpson 法またはHodgkinson \& Williams の方法によつた. これらの方法の詳細につ いてはすでに報告した ${ }^{5)}$ ，後者は前者よりすぐれている と考觉るが，われわれは研究の初期には Yarbro \& Simpson 法のみで定量して和り, 本報告半分の症例はこの時 期に測定したのでこの方法による測定值も含んでいる. 本論文では葆酸量は無水蓚酸として計算した。また， 比較が正確に行なえるように，個々の例の值は体表面積 $1.73 \mathrm{~m}^{2}$ 当たりの蓚酸量に補正してある.

\section{実験成績}

1）尿管回腸膀脱吻合術実施患者の尿中苳酸排泄量 対象とした患者の年齢, 性, 原疾患, 術式, 術後年 数，扣よび蓚酸排泄量は表 1 亿記した．回腸を使用する 尿路変更術を受けた患者 8 例の苳酸排泄量の平均は33.5 \pm 3.4 (S.E.) $\mathrm{mg}$ であり, その範囲は $17.4 \sim 48.1 \mathrm{mg}$ であつ 
表 1 回腸を使用した尿路変更術後の尿中葆酸排泄量

\begin{tabular}{|c|c|c|c|c|c|c|c|}
\hline 患＼cjkstart者 & 年 令 & 性 & 原 疾 患 & 手術々式 & $\begin{array}{l}\mid \text { 使用回腸の } \\
\text { 長さ }(\mathrm{cm})\end{array}$ & 術後年数 & $\begin{array}{l}\text { 24時間尿中の無水葆 } \\
\text { 酸量 } \mathrm{mg} / 1.73 \mathrm{~m}^{2}\end{array}$ \\
\hline M. S. & 24 & $\mathrm{~F}$ & 両側腎結核 & $\begin{array}{l}\text { 尿管回腸膀 } \\
\text { 胱吻合述左 }\end{array}$ & 20 & 5 年 7 月 & $\begin{array}{lll}23.1 & 41.0 & 29.7 \\
\text { 平均 } 31.3\end{array}$ \\
\hline A. Y. & 41 & $" \prime$ & 子宮 癌 & " 两側 & 35 & 2 年 8 月 & 30.0 \\
\hline M. S. & 48 & $" 1$ & " & " $"$ & 35 & 9 年 1 月 & 17.4 四均 \\
\hline N. Y. & 47 & $" 1$ & " & " " & 35 & 10年 7 月 & $\begin{array}{lll}50.7 & 58.6 & \text { 平均 } \\
40.2 & 20.9 & 42.6\end{array}$ \\
\hline H. T. & 45 & $" 1$ & " & " 左側 & 30 & 2 年 2 月 & 48.1 \\
\hline I. K. & 64 & $" \prime$ & " & " 右側 & 30 & 2 年 2 月 & 42.2 \\
\hline U. K. & 33 & $" \prime$ & " & " 両側 & 20 & 1 年 0 月 & 33.3 \\
\hline H. M. & 29 & " & " & " 右側 & 20 & 4 年 6 月 & 23.4 \\
\hline
\end{tabular}

対照成人女子 ( 8 例) の 24 時間尿中無水蓚酸量 range: $24.6 \sim 47.3 \mathrm{mg}$ mean: $32.7 \pm 2.6$ (S.E.) $\mathrm{mg}$

平均 $33.5 \pm 3.4$ (S.E.)

た。教室に拉けるほ注同年齢女性の 正常者 8 名の平均 は32.7土2.6 (S.E.) $\mathrm{mg}$ であり, その範囲は24.6 47.3 mgであつた. 推計学的に両群の苳酸排泄量に差はみられ なかつた。また，使用腸管の長さ，手術より苳酸定量ま での日数も何等の関係を認めなかつた。検査した 8 例は すべて術後経過良好で腎機能も良く保存されて括り，結 石合併はない，これらより，尿路変更術に使用する程度 の長さの回腸を昿置しても苳酸代謝には影響を与兄ない と考兊た。

2）小腸切除術を受けた 1 症例の尿中蓚酸排泄量 42歳男子. 20 歳のとき腸結核のため回腸切除を受け, 23歳执よび38歳のときゆ着のため, さらに, 回腸切除を

図 1 腸結核により回腸切除を受けた 1 症例の 6 日 間連続測定した 24 時間尿中無水蓚酸量

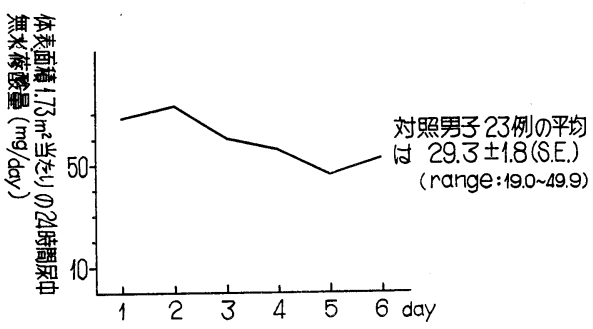

受けた。これらの手術の結果, 切除は約 $1 \mathrm{~m}$ に打よん だ.この 4 年後腎結石となり，当科を括とずれた症例に つき蓚酸排泄量を測定した。図 1 に 6 日間の 24 時間尿中 蓚酸量を示した。これらの值は原発性過葆酸尿症のそれ に比較すればはるかに低值であるが，正常者に比べれば 明らかに高值である。よつて，本症例は最近注目されて いる回腸切除あるいは腸疾患による続発性の過苳酸尿症
であると考えられた、結石の成分は苳酸カルシウムより 成つていた。

\section{考按}

腸疾患が過蓚酸尿症，さらには尿路結石と関連のある ことが報告されたのは Smith ら ${ }^{67)}$ 亿始まる．限局性腸 炎 5 例, 腸硬塞 1 例, 腸閉塞 1 例の回腸末端部を切除さ れた患者に尿中苳酸量が增加し苳酸カルシウムよりなる 腎結石が見出された 加じ，また，結石は有さないが回腸切除を受けたもの 18 例中 5 例に過蓚酸尿を見出した. 同様の過苳酸尿は腸 内細菌の過剩発育を示するのや非熱帯性スプルー, 肝硬 変等のうちにも認められた ${ }^{1)}$ ，小腸の切除あるいはその 疾患と結石との因果関係はその後も症例が見出され，イ ギリス怙よびミネリタ, カリフォルニア両州で同様例が 1972年までに50例以上集計された ${ }^{9)}$. Chadwick ら 腸切除を受けた18例中12例に過蓚酸尿を見出し，このう ちの 3 例は尿路結石を合併したと報告した. 肥満症の治 療のために行なつた腸のシャント手術後にも腎結石の発 生が警告され，34例中11例に見られたといら ${ }^{10)}$.このう ち 9 例は空腸結腸吻合術, 2 例が空腸回腸吻合術であつ た. Coe ら ${ }^{11}$ は腎結石 230 例中炎症性腸疾患に由来する ものが 9 例ありとした。

回腸切除の長さと過苳酸尿との間に当然因果関係があ ることが推定される. Smith ら ${ }^{8)}$ の症例は切除回腸は40 cmより回腸全長に及ぶし, Chadwick $ら^{3)}$ の 18 例は $30 \mathrm{~cm}$ から $540 \mathrm{~cm}$ であり，一般に切除範囲の長いほど尿中苳酸 排泄量は大さい様である。また， bypass 造設のときはそ の部位や長さが影響を与えるようで, 前述の空腸結腸吻 合は空腸回腸吻合より結石発生が多いのもそのためであ ろう. 著者らの症例は尿管回腸膀胱吻合術の場合昿置回 
腸の長さは比較的短かいことが尿中苳酸排泄量に影響を 与兄ない理由であろう. 数回にわたり回腸切除を受け, その後結石となつた1 例は Smith ら ${ }^{8)}$ の報告と類似して いたものである。

小腸の疾患や手術が過蓚酸尿をおこす理由については いろいろ議論された．Smith ${ }^{1)}$ によるとこれらの症例 では胆汁酸塩の合成が充進するため正常のときこれと 結合するタウリンが不足し，グリシンと結合する様にな る. 後者が回腸末端での吸収不全のため大腸に流入し, 腸内細菌によりグリシンを遊離し，これが苳酸前駆体の glyoxylate となり吸収されるためとした. タウリン投与 は尿中蓚酸量を減ずるし,また胆汁酸塩と結合するコレ スチラミン投与が尿中苳酸量を減少させることもこの説 を支持した。しかし，これらの患者に尿中 glyoxylate の排泄が増加して招らず ${ }^{122},{ }^{14} \mathrm{C}$-glyoxylate 静注後尿中 苳酸への移行の亢進もなく, cholyl ${ }^{14} \mathrm{C}$-glycine 投与で グリシンは苳酸にとくに移行せず ${ }^{3)}$ ，さらにはタウリン の無効例があるに扣よび疑問視され，Smith $5^{8)}$ も後に この説を全面的に否定した.

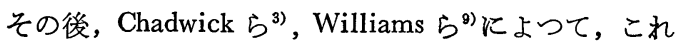
らの患者に ${ }^{14} \mathrm{C}$ - 苳酸を投与すると, 正常者に比して, 尿 中落酸によく移行することから苳酸の吸収が充進してい ることが見出され, 低蓚酸食でもこれらの患者の尿中苳 酸量が低下するにより苳酸の吸収方進説が支持された。 また，患者に対するグリシンの投与も尿中苳酸量を増加 することから落酸前駆体も影響を及ぼすようである。

腸における苳酸吸収の充進は吸収されない脂肪とカル シウムが結合するため, あるいは空腸内の胆汁酸濃度の 低下等も考号らているが3)，まだ確証はないようであ る.また, 腸疾患による結石形成者でも必らずしも尿中 苳酸排泄量が増加していないといら報告もある ${ }^{10)}$. 過葆 酸尿と結石形成との間にもいろいろと発生条件が必要で あり, 単純には論じられないであろう。

続発性過苳酸尿は腸疾患の他に文献的にはいくつかあ げられている (表 2$)^{19913) . こ の ら ち ， ヒ ゙ タ ミ ン C 大 ~}$ 量投与 ${ }^{14)}$, 表に示された種々の疾患 ${ }^{15)}$ はあまり関連性が そしいようである。著者等の測定ではクラインフェルタ 一症候群の患者はすべて正常範囲であつた.

これらの患者の治療としては低苳酸食が良いであろう し、コレスチラミンも苳酸と結合し, 吸収を阻害するた めに用いられている. 著者らの結石を発生した症例でる 今後長期間の食慨指導をする予定である.

\section{結 語}

回腸を使用して尿路变更術を行なつた患者 8 例の尿中 苳酸量を測定したが, 対照に比し差は認められなかつ
表 2 続発性過苳酸尿症の原因
1. 蓚酸あるいは蓚酸前駆体の多量摂取 （大黄, エチレングリコール等）
2. ビタミン $\mathbf{B}_{6}$ 欠乏
3. フローセン麻酔
4. ビタミン Cの多量摂取
5. 種々の疾患 (サルコイドーシス, 肝硬変,
腎尿細管性酸血症等)
6. 腸疾患（回腸切除）

た。したがつて, 尿路変更術に用らる程度の長さでの回 腸の使用は蓚酸代謝に異常を来さないと考元た。頻回小 腸切除後腎結石を発生した 1 症例に過蓚酸尿をみたので あわせて報告した。

\section{文献}

1) Smith, L.H., Fromm, H. \& Hofmann, A.F.: New Eng. J. Med., 286, 1371, 1972.

2) Admirand, W.H.: New Engl. J. Med., 286, 1412, 1972.

3) Chadwick, V.S., Modha, K. \& Dowling R.H.: New Engl. J. Med., 289, 172, 1973.

4) 伊藤晴夫 : 医学のあゆみ, 83, 351, 1972.

5）伊藤晴夫：日泌尿会誌, 66, 19, 1975.

6) Hofman, A.F., Thomas, P.J., Smith, L.H. \& McCall, J.T.: Gastroenterology, 58, 960, 1970.

7) Smith, L.H., Hofmann, A.F., McCall, J.T. \& Thomas, P.J.: Clin. Res., 18, 541, 1970.

8) Smith, L.H., Hofmann, A.F., Tacker, M.M., Fromm, H. \& Thomas, P.J.: In Urinary Calculi. Int. Symp. Renal Stone Res., Madrid 1972, pp. 31-40 (Karger, Basel 1973).

9) Williams, H.E., Earnest, D. \& Admirand, W.: In Urinary Calculi. Int. Symp. Renal Stone Res., Madrid 1972, pp. 41-45 (Karger, Basel 1973).

10) Dickstein, S.S. \& Frame, B.: Surg. Gynecol. Obstet., 136, 257, 1973.

11) Coe, F.L. \& Kavalach, A.G.: New Engl. J. Med., 291, 1344, 1974.

12) Admirand, W.H., Earnest, D.L. \& Williams, H.E.: Trans. Ass. Amer. Physicians 84, 307, 1971.

13) Hagler, L. \& Herman, R.H.: Am. J. Clin. Nutr. 26, 1073, 1973.

14) Briggs, M.H., Garcia-Webb, P. \& Davies, P.: Lancet, II, 201, 1973.

15) Dempsey, E.F., Forbes, A.P., Melick, R.A. \& Henneman, P.H.: Metab. Clin. Exptl. 9, 52, 1960.

（1975年 10月 20 日 受付） 